\title{
What we can learn from intergenerational collaboration in research?
}

\begin{abstract}
The purpose of this biographical paper is to reflect generational changes in the landscape of educational sciences during the last 20 years. Rapid change within the educational science generations on the one hand, and in the gap between the research-generations has been observed in the last years at the international level. despite this fact, the intergenerational collaborative research has had impact on carrier advancement of younger research generations. Therefore, this paper aims to find out the evidence on what we can learn in intergenerational research collaboration. The theoretical background of the current paper is based on the human collaboration concept in the form of transfer and transforming the best practice patterns and developing self-experience with new knowledge, skills, and attitudes (špona, 2018: 18). The ethnomethodology of ex-post-facto innerdialogue' was chosen to find answers to the research question, targeted on reflecting on collaboration as social life impact on selected different researcher generation cases with the career advancement from school teacher to scientific institute director as a method of analysis of the human collaborative practice of perceiving people, places and events as "categories" of "collaboration," and to use these to explain collaborative actions. the evidence of scientific, social and practical impact of intergenerational collaboration, and the sustainability of collaborative research will be explained, based on experience with the excellent team of West-Timisoara University. Biographical intergenerational collaboration stories of three research generations have impacted research career advancement and will contribute to the international discussion on what we can learn from intergenerational collaboration in research.
\end{abstract}

Keywords: educational research, generational change, intergenerational collaboration

\section{Introduction}

The purpose of this biographical paper is to contribute to the discussion in the Journal of Educational Science on generational changes in the landscape of educational sciences during the last 20 years, for the anniversary issue.

The topic of this special issue of the journal seems to be extremely timely because of the rapid change of the educational science generations, and there is only little time left to observe and reflect collaboration practice of three

\footnotetext{
• Irina Maslo - Professor, Dr. habil paed, University of Latvia, irina.maslo@lu.lv
} 
generations of educational researchers currently working simultaneously at the University of Latvia.

The idea is timely also, because the collaboration between the researchgenerations has crashed in the last years, which does not depend on the institution's or the country's contexts, but on global development. This becomes evident through the observed educational research practice, through communication between the researchers themselves, and with international students.

The theoretical background of this biographical paper represents three research generations at the Scientific Institute of Pedagogy of the Faculty of Education, Psychology and Art of University of Latvia (further named in text as 'Institute of Pedagogy or Institute'), and is built on two theses of my supervisor, professor, Dr. habil. paed. Ausma Špona, the founder of pedagogy of collaboration in Latvia in the 1990s:

1) In Latvia in the 1990s, the essence of the paradigm of pedagogy is changing - the pedagogy of authoritarian action moves to a pedagogy of human collaboration, in which two or more people move towards a common goal with mutually agreed means of achievement, approximating assessment and self-assessment of achievable results (Špona, 2018:18);

2) Collaboration is a form of transfer of experience, the ability to transform the best practice patterns developing self-experience with new knowledge, skills, and attitudes (Špona, 2018:18).

The research question is generated from the main question considered by my supervisor in her life and work: "Will people benefit from my living and working? What can I do to help people, society, the state, and science?" (Bernāne, 2006). This is not surprising, I think. Having the great opportunity to work together with the "biggest", in my opinion, national pedagogical research personality of the Millennium era, I come to the understanding, that her thought has grown into my blood with the same question: Why did life give me this unique opportunity to grow as a researcher, along with and together with this outstanding, in my opinion, personality? What can I personally do to help people, society, the state, and for the development of Latvian national pedagogy?

The ethnomethodology of ex-post-facto 'inner-dialogue' was chosen to find out the answers of the intended research question, targeted on reflecting of collaboration as social life impact on three selected different researcher generation cases with the career advancement from school teacher to the scientific institute director as a method of analysis of the human collaborative practice of perceiving people, places and events as "categories" of "collaboration," and to use these to explain collaborative actions (Eglin \& Hester, 2006:48). Analysis of biographical career advancement stories of my scientific supervisor, myself and my doctoral students, was conducted using the own experience of doctoral study on impact of collaboration on active life position of collaborators in biographical contexts at the starting point of my own research career led in defence of doctoral theses (Maslo,1987). 
Starting from three biographical doctor degree interconnected generation biographical stories of rapid career advancement as a researcher - of my doctoral theses supervisor, my self-selves and my doctoral students who thanks not least to the collaboration with West- University Timisoara, conducted the first joint studies with publishing its results in the current journal. These joint studies will be especially reflected biographically, augmented through the biographical evidence on career advancement, related to the paper purpose to discuss on what we can learn from intergenerational collaboration in research.

\section{Three research generation career stories}

\section{Research carrier advancement story of my supervisor, Ausma Špona, born in the 1930s}

My dear "doctor mother", on the acquisition of the profession 1949, graduated $7^{\text {th }}$ Grade, entered the Cēsis Teachers' Institute in Latvia. In an interview to an official national magazine the professor tells:

The only entrance exam I had was - a musical hearing test. We fought at the institute to become excellent and get a bigger scholarship. We never went out to prepare us for the seminars. Collaboration between senior and younger students was particularly valuable" (Gžibovska, 2006).

Teaching pedagogy at University of Latvia since 1965, the professor got the Doctoral degree in pedagogy (Dr. habil. paed.) in 1983, and the title of professor - in 1984 (Latvijas Enciklopēdiskā vārdnīca,2016), becoming the head of the Department of Pedagogy and Psychology as the permanent department of University of Latvia, led it from 1983 till 1996. In 1986-1990 the University of Latvia Scientific Council in the field of pedagogical science was working actively. 40 scientists have obtained their Ph.D. degree in Pedagogy in this time-span. On June 17, 1996, the Senate of the University adopted the decision No. 53 "On the establishing the permanent Institute of Education and Psychology of the University in Latvia". The Rector's order was to reorganize the Department of Pedagogy and Psychology into the Institute of Pedagogy and Psychology on August 1, 1996, led by a professor in 1996-2000 (PZI, 2015).

Dr. habil. paed. Ausma Špona is currently the oldest acting professor in pedagogy. Her research engagement in general pedagogy, theory, and methods of upbringing are still in development. She participated in international research studies together with scientists from Germany, the Netherlands, Greece, Spain, and Russia. Since 80tis of the 20. century, under her scientific guidance, 64 dissertations (including of the author of this paper) have been defended and a number of current doctoral dissertations for prospective Latvian and German researchers in pedagogy (Špona, 2018) are supervised by the professor "as voluntary researcher" at the University of Latvia, is the author of more than 200 scientific and methodical publications, 14 monographs and collective monographs (Špona, 2018).

Her human pedagogical ideas built the School 2000 reform and built the base of the School 2030 reforming in Latvia today. 


\section{Research carrier advancement story of the author of the current paper, born in the 1950s}

As an innovative school and HE teacher, defended in 1987 the promotional theses "Impact of out-of-school activities on active work-life position". Habilitated in 1995 in Individualization of the schooling pedagogical process on the bases of international accreditation of national level innovations for learning supported schooling organization, school cross-curricula, learning-centred German as school subject curricula for 1., 2., 3. foreign language, the bilingual education models for minority education in Latvia were elaborated (Latvijas enciklopēdiskā vārdnīca, 2006).

Since 1997 - a professor of the University of Latvia, throughout this period, serving as a creator, implementer and director of the Institute of pedagogy (faculty department) of the University of Latvia (2007 -2015), and the Head of the Scientific Council of the same Institute (2015-2019), creating, implementing and directing (2007 -2016) the master's degree programme on Educational Treatment of Diversity. Leading the Doctoral school "Human capacity and lifewide learning in inclusive contexts of diversity". Consulting expert of national curriculum development and European adult educational policies development in Ecorys and EduMap Horizon 2020 program projects.

Research, publications and supervising of 15 defences and 5 current doctoral theses covering the lifelong learning (LLL) practices: learning activity for promoting primary school pupils' social competence; development of adolescents' social-cultural competence; youth participation in integration process in multicultural environment; the learning outcomes approach in formal second chance education of youth in vulnerable personal situation; opportunities of applying continuing bilingual, intercultural and inclusive education experiences for inclusion of third-country nationals; integration of science teacher and educator identities through student's pedagogical activity; self-directed learning at university; mentor's support to science and languages teacher's team in the implementation of bilingual learning as innovation in continued training; transversal skills and main attributes of constructivist transformational learning activities for promoting excellence in education and workplace training.

\section{Research career advancement story of my doctoral student, born in1970s,}

Leading researcher, Docent, Dr. paed. Manuel Fernandez J. Gonzalez, a young researcher with the excellent career from music teacher to career of leading researcher in 5 years at the University of Latvia, Vice-head of the Promotion Council in Pedagogy at the University of Latvia, was elected as director of the above-named institute in 2015, responsible for the research programme "Human, technologies, and quality of education" of the University of Latvia, and 2017 hold the young researcher research and innovation post-doctoral grant for 2017-2020. As elected member of the international network "Leadership and quality of education" and co-convenor of ECER network on quality of education, he holds lectures and seminars on research methodology for 
graduates and postgraduates at the University of Latvia, encompassing the computer-assisted (INTERACT 17 software etc.) qualitative analysis on teachers' virtuous leadership, character education, professional identity and pedagogical leadership of university staff, vocational education and training.

In 2015-2017, he was an international coordinator of the interuniversity master studies programme on educational treatment of diversity contributed to the implementation of e-learning at the university.

His recent post-doctoral research proposal is to implement a web-based research program called ARETE for TC\&CE instruction by schools. The research proposal is innovative as it will focus on the combination and reconciliation of Character Education and Transversal Competences for teaching. Under this umbrella, the proposal will address research questions which are relevant for the modernization of education in Latvia and provide a scientific foundation for design/implementation of online platforms which support Transferable Competences and Character Education. Regarding the topicality of the project, the proposal is aligned with the development of the Latvian economy and society. That is, the proposal contributes to fulfilling international recommendations and ongoing actions in the education systems in Latvia (Development guidelines for education 2014-2020, Career education project 2013, etc.). Nevertheless, combining character education and transversal competences together is relevant for the new Latvian economy and society and reformation of school education to School 2030.

His research has led to a wonderful career from 1990s orchestral and faultsoloist in France, Latvia and Lithuania. Finland, Switzerland and Germany acting as director of the Music school in France (Strasbourg) and as Head of the department in St-Louis conservatorium in Alsace (France) to Latvian Catholicaschool and France-lyceum in Riga choir conductor and teacher of Spanish as foreign languages in 2004-2009 and rapid scientific career from research assistant to leading researcher and research institute director, and individual research and innovations grand holder would be worth its own exciting narrative story and exploration.

\section{Research conducted in a dialogue between research generations}

The first collaborative research opportunities for my generations young researchers were provided by the first director of the Institute of Pedagogy, professor Ausma Špona, in 80s-90s given as the intergenerational learning opportunities in joint European level research methodology development projects led by professor Josef Held (Tubingen University) by conducting of quantitative and especially qualitative research on video-recorded "youth voices" in multicultural learning. These research settings are open until nowadays for all research generations but are actively used only by the second and third, nor by the first and fourth generations. 


\section{The German collaborative research space}

This German collaborative investigation space was extended thanks to the collaboration opportunities inside the University of Tubingen with professor Gunter Huber from the same University, involving us since 2003 in approbation and development of new computer-supported text, pictures, audio-and videotapes analyses software AQUAD 5-7 (Maslo et all, 2008), so as in collaborative Spanish speaking research space which was continuously developed later by the third generation of young institute directors in last 10 years.

\section{The Spanish collaborative research space}

The Spanish collaboration space allowed to implement the competence oriented (Maslo et al, 2006) inter-university e-master's programme 'Educational Treatment of Diversity' in 2008-2010 as the first pattern in Latvia versus distance learning with broad opportunities to conduct evaluative studies on its impact of the learning outcomes of students at the university.

A study conducted during the implementation of this master degree programme in 2008-2010 (Birzina et al, 2012) explored how challenges were secured in e-learning in order to promote students' generic competence at universities as promoters of lifelong learning. E-learning is a means of promoting the changes in academic studies and provide broad opportunities to integrate non-formal and informal learning elements into formal education by individualisation (Maslo, 1995) of learning opportunities flexible in time as well by creating the e-environment which facilitate the development of students' generic competences.

The next study on university teacher's competences needed in 21. century and specially to implement e-learning at the universities was conducted in 20102012 (Surikova et al, 2009).

The secondary qualitative data analyses allowed to construct the evidencebased theoretical model of e-learning and explain the subjective and objective conditions to have been ensured for the sustainable e-learning at universities (Maslo et al, 2014). Least, but not last, in my opinion, the collaborative activities provided in the programme from 2015 to 2018 were analysed unseeing learning analytics to explain the theoretical model of collaboration in e-studies, just as in the publishing process of West-University Timisoara's new academic book by Sense-Brill (Maslo, in publishing 2019 August).

\section{The Asia and Europe collaborative research space}

The Asia-Europe collaborative research space was opened to us at the same time, in 2008, thanks to the invitation to participate in the Asia-Europe official research network in lifelong learning (ASEM LLL) by Professor Dr.h.c. mult. Arne Carlsen, the founder, establisher and empowerer of this network. The research opportunities for all three generations of researchers were extended to all European and Asian countries, including Romania, represented by the WestUniversity Timisoara. The University of Latvia is the only European university that participates actively with the institute researchers in all its five subnetworks, and conducted studies with joint publications, that are listed on the ASEM LLL HUB web-page. 
Active participation as partners in the two first international projects was the first quality proof of research capacity of our intergenerational team. These projects, initiated and practically led by German and Romanian adult education institutes and West-University of Timisoara as Members of ASEM LLL Hub, opened new important international research directions showing the ways for creating research innovations in 2010-2012:

The first one - creating a new online learning environment to support the development of the entrepreneurial competences for young people and graduates, where we have jointly in international small teams evaluated the training needs and learning interests of young entrepreneurs to identify the interest domains for starting a business from youngsters, that are going to graduate, and potential barriers, so as to define a curriculum for developing entrepreneurial competences, using eMentorship. A transnational needs analysis report of the CReBUS project "Creating a business in the digital age developing entrepreneurship competencies for young Europeans through eMentorship" was developed by the Latvian partner (Surikova et al, 2013). An online guide on quick start of a business and a Booklet "Entrepreneurship for Students in Social Sciences" (Ardeleanu et a, 2012l, the proceedings of the International Conference "Entrepreneurship Education - A Priority for the Higher Education Institutions - CReBUS" (Surikova \& Maslo, 2012; Surikova \& Pigozne, 2012; Maslo \& Fernandez, 2012; Fernandez \& Vostrikovs, 2012;) and joint publications were published, e.g. in the current Journal (Martin et al, 2011).

The second one aimed at developing and maintaining a European network that will promote the implementation of the Validpack instrument in over 20 European countries to raise awareness of the existence of the Validpack - a competence assessment instrument for trainers resulting from the VINEPAC project,- in all European countries by establishing national Validpack contact points to identify the need, usefulness and potential of the Validpack instrument in different national contexts by conducting testing of Validpack in interested organisations and most likely to further use the instrument in assessment centres, adult education centres/ institutions, professional associations, employers, etc.. The validation of informal and non-formal psycho-pedagogical competencies of adult educators, especially the by the Validpack instrument that facilitates the documentation and the evaluation of trainers' competences acquired in formal, non-formal or informal learning contexts, were created and published (Duvekot and Geerts, 2102), and further in a set of joint publications in the current journal (Surikova et al, 2012, Rutka et al, 2012, Maslo et al 2012).

The third one was the first project by our intergenerational research team for international ASEM LLL. It was an export study aimed at elaborating evidencebased recommendations for LLL policy 2016-2020, for regional communities and society as a whole. The evidence-based recommendations of these studies had a high impact on the National reform programme of Latvia 2016-2020 for the implementation of the" Europe 2020" LLL strategy. This study explored by mixed-method analysis of early school-leavers' and evening schools teachers' 'voices', through a field study on second-chance education, conducted in close 
collaboration with evening schools, local and regional environment, and national authority bodies in a comparative Asian and European Life-Long Learning (ASEM LLL) perspective. Based on evidence on reasons to leave schooling early, the recommendations on creating a universal, selective and indicated system of preventive, compensatory and monitoring measures to solve the problems of early school leaving, was developed by ASEM LLL experts from India, Latvia, Lithuania, and the Philippines.

This project as well as the next three projects challenged us to a higher level of responsibility, creativity level of independence, high level of initiative and demonstrated our high-level satisfaction with participation (Maslo, 1987:109) in research being responsible for people, state and science) (the research result had been an EU ex-ante condition for investment for 2016-2020).

Currently three institute projects 2016-2019 have challenged our intergenerational researcher team to act as experts in two Erasmus+ KA2Capacity Building in Higher education projects for the development of the eSTEM programme and integration of special needs inclusive education, in Egypt and Arabian countries, and one national level project for promoting the reform School 2030 by implementation of character and value education.

These projects enable us to work with highly qualified partners in these fields, nowadays so important for Higher education, using the most up-to-date innovations in teacher education in eLearning and ICT. In this project, we will also carry out a transformative study to create an innovation culture in Latvia, in cooperation with industry specialist service partners, creating synergies with the business and promoting scientific cooperation with the national economy.

These three main research spaces, created at the Institute of Pedagogy and led by all three research generation representatives, gave master and doctoral students active participation opportunities in joint national and international projects providing them not only their own benefits as researchers in career advancement and rapid permanent and sustainable employment as young or third generation researchers, but also intergenerational learning opportunities to conduct research for people, society, the state, and pedagogy as science by learning from patterns of high-level responsibility, creativity level of independence, high initiative level and satisfaction from one's own attitudes in active participation in research activities, and becoming respected as a teammember at national and international level on the one hand, but on the other hand, stipulated a gap between the first German-speaking research generation and a new English speaking generation, because the switching into the English speaking research spaces, as a new requirement in research career advancement, were most challenging for most first generation German orientated researchers. In particular, therefore, the author of this paper is happy for the opportunity to show the intergenerational collaboration opportunities of researchers from different spaces using diversity as a positive and enriching factor. Other factors impact the gap between the new, fourth and the previous research generations, what I think will be useful to discuss in this paper. 


\section{Discussion}

In my opinion, this gap between the research generations roots neither in the challenges of the information society, nor in advanced technologies. It roots, on the one hand, in fragmentation of the narrow new-liberal commercialised specialisation of education and lack of systemic views on humans as personality in educational settings, what has been slowly lost in the last 20 years, and in moving from active life-work position to the personal images position acting as actors empowering themselves to be the main actors on the "life-work stage" on the other hand, which is evident through observations, face-to-face and social media communication too, word wide.

Professor Špona (2018) writes:

A 21st-century human differs from other historical epochs of homo sapiens with exceptional understanding of the values of life. This is evident through the individuals' and social groups' need for self-realization. People want to improve their well-being, work and get paid, get education and health. (Špona, 208:16).

A rapid change in the situation in society requires predicting the futureoriented development of pedagogically-based cognition, the possibility of providing education to everybody for being able to manage one's own learning and to be self-confidence (Špona, 2018:16).

The interdependence of providing each individual of the society with opportunities to acquire full-fledged education, on the one hand, and personal responsibility for self-education, learning and self-development results, on the other hand, has an impact on the subject of pedagogy (Špona, 2018:16).

The learning of the new generations has to be based on the concept of holistically of nature, people and society. Attitudes to themselves, peoples around, nature and sociality is the key to human development, write professor in 2001 (Špona, 2001) and in 2018; Špona, 2018:21):

Biosphere or human and nature content is made up of the natural environment, space, production, and economic processes, ecology, living and inanimate nature. The second sphere is the system of human and social relations - the social sphere. By recognizing this sphere, a child, a young person, an adult, is aware of himself as a social being responsible for people, society and himself in accordance with his conscience and the needs of society. The content of the third sphere is formed in the person itself: selfawareness of consciousness, cognitive need, rational and emotional thinking, self-regulation of behaviour, acquisition of personality traits and abilities. It is a human psycho-sphere.

In the manifestation process of psychic mind and emotional attitude, the transition from the inner form of activity of the mind to external (practice: speech, action, behaviour) activity takes place (Špona, 2018:17).

And she cites, what the Italian literature scientist and philosopher Nuccio Ordine (born 1958), who has been involved in the world-scientists' 
discussion on the value message in modern life and the principles of material distribution, says ${ }^{1}$ :

The knowledge itself is an obstacle to money omnipotence and utilitarian delusions. You can buy everything, right, from parliamentarians and finally with judges, from power to success: everything has its own price (Ordine cited in Špona, 2018:16).

In the name of economic interests, the memory of the past, humanitarian disciplines, classical languages, education, free research, fantasy, art, critical thought and a cultural horizon that should inspire every area of human activity (Ordine cited in Špona, 2018:16).

As a practiced school and high school teacher and doctoral student of the professor, Ratniece (2014), cites what the professor tolled about the collaboration in the interview:

The social constructivists, as well as human pedagogy representatives, thus maximize the significance of the correlation between the learner and the teacher trainer or teacher in the teaching/learning process. Millennium Goals advocates continue that reality is created by our own actions, activities (Ratniece, 2014:226).

These three research generations biographical ex-post-facto inner dialogue on collaboration impacts research career advancement and will contribute to international audience discussion on what we can learn from intergenerational collaboration in research.

\section{Conclusion}

We can learn from intergenerational collaboration in research:

1. The key to collaboration is the researcher attitude. The term, "Attitude" finds an English equivalent only a few years' ago and is a transversal idea of all scientific work and life of the professor (Špona, 2001; 2009; 2018). This idea is at the centre of the School 2000 reform and of the School 2030 reforming in Latvia today.

2. The unique intergeneration research opportunities provided by my supervisor in 90s, let us together implement a number of innovations at the Latvian educational system level: to facilitate the implementation of individualised curricula in Latvian general and vocational schools at the national level in 1990s; and to implement bilingual education in Latvian social and cultural context.

3. Based on the definition of social activity, defined in the professor's monograph as characteristic of active acting in society (Špona,1979), the mathematical processing of author's dissertation observation data was processed to explore the features of active life position (Maslo, 1987:109). The following main features of collaboration effecting the career advancement were evident: 1) the high level of responsibility, 2) creativity level of independence,

\footnotetext{
${ }^{1}$ Ordine N. Nelietderīgā derīgums. Rīga: Jāṇa Rozes apgāds, 2017, p.14
} 
3) high level of initiative and 4) satisfaction with participation in research activity.

4. In fact, the intergenerational collaboration in research affects the synergy of ideas which in a cyclical sequence transforms the theoretical constructs in more and more universal applicable practical knowledge:

Processes in the society nowadays change the position of the person - from the performer of actions to an active, independent and responsible actor. It is promoted by new upbringing ideas in the work of philosophers, educators and also social and exact scientists (Špona, 2018:18).

Along with the change of position of learners in pedagogical processes in schools and universities, new pedagogical ideas are created and theoretically defined but not yet implemented in methodological approaches to pedagogical practice. First of all, it is an idea of the purpose of upbringing as an important factor in the pedagogical activity that would promote the formation of a free, independent and responsible pupil, student personality in the study/study process (responsible, free in choice, independent and active acting). The goal is predicted and achieved in action. (Špona, 2018:18).

The main requirement for goal achievement is the active participation of scholars and students in the choice of study content and forms. Participation in the course learning activities becomes the main means of upbringing in the process of formation of a free, independent and responsible personality (Špona, 2018:19).

The Latvian intergenerational collaborative research attempt to redefine human competences by connecting with the process of self-transformation. Communication and collaborative competences are closely related to one's reconstruction of the self as a collaborative researcher.

The scientific, social and practical impact of our intergenerational collaboration is evident through the fact, that Latvia was selected in 2016-2019 Horizon 2020 project as good practice to validate the informal learning of young adults and implementing and directed (2007 -2016) master's degree programme on Educational Treatment of Diversity, which was selected by the Directorate-General for Education, Youth, Sport and Culture (European Commission) as one of the 15 best European cases on preparing the teachers for diversity in 2017 and included in the EU School Gate directory (EC, 2017).

The sustainability of collaborative research with an excellent team of WestTimisoara university, led by prof. Dr. habil paed. Simona Sava is evident, not least through this paper contribution alongside many other joint activities inside and outside the Asia and Europe LLL Hub education and research official networking.

\section{Acknowledgments}

I would like to thank all the Latvian first generation researchers in psychology and pedagogy: my doctoral thesis supervisor, professor Dr. habil. paed Ausma Špona, docent Ludvigs Grudulis, professors Leonards Žukovs, Imants Plotnieks, Dzidra Meikšane, and Ārija Karpova, and all colleagues having 
played a role for me in my life and work and having provided learning and collaboration opportunities for younger research generations.

My special thanks to Editor in Chief of this international well-known and recognized journal, Professor Simona Lidia Sava, and all colleagues of WestUniversity Timisoara, for promoting the career of me and my doctoral students, with Latvian educational science internationalisation in these 20 years, providing generational collaboration inside and outside of my own country on the one hand, and internationalisation of Latvian national pedagogy, on the other.

My special thanks to Professor Dr.h.c. mult. Arne Carlsen, currently Visiting Professor of the Faculty of Education, Psychology and Art of University of Latvia, the Founder of the Asia-Europe official research network of leading universities in Lifelong learning (ASEM LLL HUB), a career advancement space of the author of this paper and my doctoral students. He provided insight and expertise that greatly assisted the writing of this paper for an international audience.

\section{References}

Ardeleanu, Anca Monica; Papuc, Razvan Mihail; Bratu, Anca (2012). Entrepreneurship for Students in Social Sciences. CReBUS project team: Magdalena Platis; Monica Ardeleanu; Razvan Papuc; Simona Sava, Laura Malita, Catalin Martin; Gerhard Doppler; Javier Farto Lopez, Carolina Paneda; Irina Maslo, Svetlana Surikova, Tamāra Pīgozne, Manuelsernandezs; Stefano Tirati, Giovanni Crisona, Anna Sarateanu; Renata Prokeinova, Iveta Zentková, Andrea Zalabaiova. Timisoara: Mirton.

Birzina, Rita; Fernate, Andra; Luka, Ineta; Maslo, Irina; Surikova, Svetlana (2012). Elearning as a challenge for widening of opportunities for improvement of students' generic competences. E-Learning and Digital Media, 9(2),130-142.

Bernāne, Anna-Dzidra (2006). Ausmas Šponas devums pedagoǵijā,. Retrieved from: https://www.atlants.lv/referats/ausmas-sponas-devums-pedagogija/989040/

Duvekot, Ruud and Geerts, Jeroen (2012). Handbook for the assessment and validation of pedagogical competences of adult educators (Authors: development partnership and team of the project „CAPIVAL - Capitalizing on Validpack: going Europe wide": Simona Sava, Andreea Siliman, Larisa Pirvu, Luminita Saftu, Ruud Duvekot, Jeroen Geerts, Stefanie Jütten, Anne Strauch, France Uebersfeld, Christelle Claquin, Irina Maslo, Tamara Pigozne, Manuels Fernandezs, Isabel Pardal, Cidália Rosa, Esther Cañada Herrero, Miquel Fort Marrugat, Emilia Aiello, Natalia Fernandez Alcala, Rocco Marcello Postiglione, Battista Castagna. Timisoara: Brumar.

Gžibovska, Elza (2006). Katedras vietā - institūts (Ausmas Šponas intervija Latvijas vēstnesim), Latvijas Vēstnesis (LR ofic. laikr.) Nr 153, 12.09.2006.

EC, 2017, Preparing teachers for diversity. The role of initial teacher education: final report, doi: 10.2766/637002

Eglin, Peter and Hester, Stephen (2006). The Montreal Massacre: A Story of Membership Categorization Analysis. Waterloo, Ontario, Canada: Wilfrid Laurier University Press.

Fernández González, Manuel Joaquin; Vostrikovs, Sergejs (2012). Students' intrapreneurship in Higher education settings and its relevance in the formation of entrepreneurship attitudes: a case study from Latvia. The proceedings of the 
International Conference "Entrepreneurship Education - A Priority for the Higher Education Institutions - CReBUS”, October 8-9, pp. 90-94. Bologna: Editografica.

Latvijas Enciklopēdiska vārdnīca (2006), Ausma Špona, ID: 27026. Rīga: Nacionālais apgāds

Latvijas Enciklopēdiska vārdnīca (2006), Irina Maslo, ID: 17561. Rīga: Nacionālais apgāds.

Martin, Catalin; Surikova, Svetlana; Pīgozne, Tamāra; Maslo, Irina (2011). Needs and perspectives in developing the students' entrepreneurship competences. A case study from CReBUS research project. Journal of Educational Sciences,23(1), 38-49.

Maslo, Irina; Fernandez González, Manuel J. (2015). Supporting the Engagement and Reintegration of 18-24-Year-Old Early School-Leavers in Lifelong Learning: ESF project "Support to Education Research" (sub-activity 1.2.2.3.2.). Study on Identification and analysis of new challenges and solutions that have influence on engagement and reintegration of early school-leavers (18-24 aged) in lifelong learning. Copenhagen: ASEM HUB LLL online.

Maslo, I., Surikova, S., \& González, M. J. (2014). E-Learning for Widening Participation in Higher Education. In V. Zuzevičiūtė, E. Butrimė, D. Vitkutė-Adžgauskienè, V. Vladimirovich Fomin, \& K. Kikis-Papadakis (Eds.), E-Learning as a Socio-Cultural System: A Multidimensional Analysis (pp. 21-42). Hershey, PA: IGI Global.

Maslo, Irina; Surikova, Svetlana; Karttunen, Anni; Aarna, Olav (2012). Validation of non-formal and informal learning in Latvia, Estonia and Finland: An analysis of the context. Journal of Educational Sciences,2(26), 29-41.

Maslo, Irina; Fernández González, Manuel Joaquin (2012). The central role of educational leadership for developing students' intrapreneurship attitudes in Higher education settings: a case study from Latvia. The proceedings of the International Conference "Entrepreneurship Education - A Priority for the Higher Education Institutions - CReBUS", October 8-9, 2012, Bucharest, Romania. Martin, Catalin; Druica, Elena (Eds.) Medimond - Monduzzi Editore International Proceeding, pp. 169-172. Bologna: Editografica,

Maslo, I.\& Kiegelman, M.\&. Huber, G.L. (Edition) (2008) Qualitative psychology in the changing academic Contexts Qualitative Psychology Vol VI (2008). Tubingen: Centre for Qualitative Psychology.

Maslo, Irīna et al (2006). From knowledge to competent acting. [No zināšanām uz kompetentu darbību. Mācīšanās antropologiskie, ètiskie un sociālkritiskie aspekti. Collective monograph by Akopova, Žanneta; Brante, Ilze; Briška, Ilze; Hahele, Rudīte; Helds, Jozefs; Helmane, Ineta; Klišāne, Jolanta; Maslo, Elīna; Maslo, Irīna; Ose, Liesma; Rubene, Zanda; Tiḷlla, Inta; Turuševa, Larisa. Riga: LU Akadēmiskais apgāds.

Maslo, I. (2006). Bilinguale Ausbildung von nationalen Minderheiten in Lettland. Sprachen- und Schulpolitik in multikulturellen Gesellschaften. Schriftreie des Zentrums duer Lehrerbildung und Schulforschung (ZLS) Band 5, pp. 121-143. Leipzig: University of Leipzig.

Maslo, I. (1995). Skolas pedagogiskā procesa diferenciācija un individualizācija (Individualisation and differentiation of pedagogical process of school] Rīga: Raka. Maslo, (1987). Внеклассная деятельность как седство формирования акттивной позиции подростков [Impact of out-school activities on active life positon of adolescents]. Dissertation. Riga: University of Latvia. 
Ratniece, Inta (2014). Some aspects of sustainability and synergy in the emerging teacher training, Proceeding of the International Scientifical Conference May 23th - Volume I, 24th, 225-232

Rutka, Lūcija; Briede, Baiba; Surikova, Svetlana; Latkovska, Evija (2012). Analysis of the validation instrument of adult educators' competences: The results of the Validpack second testing session in Latvia. Journal of Educational Sciences, 26(2), 42-51.

Špona, Ausma (2018). Jauns pedagogījas zinātnes priekšmets [The new research subject of pedagogy], Latvijas Zinātnes Akadèmijas vēstnesis, 7(24), 15-22.

Špona A. (2001). Audzināšanas teorija un prakse [Theory and practice of upbringing]. Rīga: Raka.

Špona, A. P. (1979) Общественная активность пионеров [Social activity of adolescents (pioniers)]. Riga: Zvaigzne

Surikova, Svetlana; Pīgozne, Tamāra; Maslo, Irina (2013). CReBUS project transnational needs analysis: concept and findings of the research". Rìga: SIA „Latgales druka”.

Surikova, Svetlana; Maslo, Irina (2012). Preferable process of entrepreneurship training and e-mentoring for business start-up: A case study of the CReBUS project. The proceedings of the International Conference "Entrepreneurship Education - A Priority for the Higher Education Institutions - CReBUS", October 8-9, 2012, pp. 233-238. Bucharest, Romania. Bologna: Editografica,

Surikova, Svetlana; Baranova, Sanita; Fernandez, Emanuel; Maslo, Irina; \& Huber, Günter (2009). Topical Needs of the Development of University Professors' Competencies, Especially Teacher Trainers' Competencies, in Latvia. Conference "Teachers and Trainers in Adult Education and Lifelong Learning. Professional Development in Asia and Europe". 29-30 June 2009 in Bergisch Gladbach, Germany. Conference-papers. Copenhagen: ASEM-HUB for Lifelong Learning. Network 3: Professionalization of Lifelong Learning with a special emphasis on teacher training. Network-Coordinators: Ekkehard Nuissl von Rein, Regina Egetenmeyer. German Institute for Adult Education.

Surikova, Svetlana; Pigozne, Tamara (2012). Entrepreneurial motivations from the students and entrepreneurs' perspectives: A case study of the CReBUS project. The proceedings of the International Conference "Entrepreneurship Education - A Priority for the Higher Education Institutions - CReBUS", October 8-9, 2012, Bucharest, Romania. Martin, Catalin; Druica, Elena (Eds.) Medimond - Monduzzi Editore International Proceedings Division, printed in October 2012, pp. 239-244. Bologna: Editografica.

Surikova, Svetlana; Rutka, Lūcija; Karttunen, Anni; Jõgi, Larissa (2012). Testing of the Validpack instrument in Latvia, Estonia and Finland: The opinions of experts. The proceedings of the International Conference "Back to Work: The Role of Validation of Competences in Professional Counselling of Adults", December 7-8, 2012, Thessaloniki, Greece. Zarifis, K. Georgios; Martin, Catalin; Sava, Simona (Eds.) Medimond - Monduzzi Editore International Proceedings Division, pp. 87-92. Bologna: Editografica.

Uebersfeld, France and Claquin, Christelle (2012). Validpack Evaluator. Quality Assurance Indicators. A Guide. (Authors: development partnership and team of the project „CAPIVAL - Capitalizing on Validpack: going Europe wide”: Simona Sava, Andreea Siliman, Larisa Pirvu, Luminita Saftu, Ruud Duvekot, Jeroen Geerts, Stefanie Jütten, Anne Strauch, France Uebersfeld, Christelle Claquin, Irina Maslo, 
Tamara Pigozne, Manuels Fernandezs, Isabel Pardal, Cidália Rosa, Esther Cañada Herrero, Miquel Fort Marrugat, Emilia Aiello, Natalia Fernandez Alcala, Rocco Marcello Postiglione, Battista Castagna. Timisoara: Brumar. 